\title{
A comparison of staff perceptions and student experiences of issues associated with university study
}

\section{Steve Briggs}

University of Bedfordshire, UK

\section{Norma Pritchett}

University of Bedfordshire, UK

\begin{abstract}
A significant body of research (Tinto, 1975; Rickinson and Rutherford, 1995; Ozga and Sukhnandan, 1998; Yorke, 1999a, 1999b, 2000a, 2000b; Yorke and Longden, 2004; Cook, 2006) has examined difficulties experienced by students who withdraw from university. However, less work has been undertaken around students who experience difficulties but choose to remain in their studies. Similarly, limited work has addressed how tutors and university support staff perceive difficulties associated with the student experience and whether these are in line with student accounts. The lack of research around university staff perceptions is surprising given that tutors must have a good knowledge of the student experience in order to be able to understand and support learning. The purpose of this study was twofold. Firstly, to examine what difficulties students reported experiencing during university and, secondly, to ascertain if university staff's knowledge of student difficulties was in line with student accounts. Using semi-structured interviews and an online questionnaire, staff and student perceptions of university difficulties were examined. Results showed that all students experienced a range of difficulties whilst studying. It was generally found that university staff had a good knowledge of the issues that students encountered. However, amongst university staff apparent 'knowledge gaps' associated with specific areas of student difficulty were identified (primarily linked to university systems and use of support services). Possible explanations for findings are offered along with recommendations as to how findings might be used by a learning developer.
\end{abstract}

Keywords: student experience; difficulties; life events; tutor awareness; university staff awareness 


\section{Introduction}

Recent Higher Education (HE) policy has resulted in significant change in the university sector in terms of student demographic and funding. The promotion of widening participation has resulted in increasing numbers of non-traditional applicants attending university (Higher Education Funding Council for England (HEFCE), 1997; 2006:

Department for Education and Skills, 2003). Changes in demographic have meant that growing numbers of students report coping with a range of commitments whilst studying. These include family commitments (Sayer et al., 2002; Hughes, 2005), relationships (Andrews and Wilding, 2004), academic work (Haggis and Pouget, 2002) and living arrangements (Christie et al., 2002; Wilcox et al., 2005; Christie et al, 2006).

Similarly, over the last fifteen years, students' financial circumstances have changed as levels of debt have steadily increased since the introduction of student loans (Hutchings, 2003). This has resulted in growing numbers of students facing increased financial hardships (Hutchings 2003; Cooke et al., 2004; Christie et al., 2005; Pollock, 2006) and needing to undertake employment whilst studying (Curtis and Shani, 2002; Hunt et al., 2004; Carney et al., 2005; Anonymous, 2006; Gibbs, 2006). Given the extent of these changes, it is imperative that staff who work in a learning development context maintain a current understanding of the modern student experience so that they are able successfully to support and facilitate student learning.

Research has highlighted a number of factors associated with why students drop out from university, such as doubts associated with course selection (Rickinson and Rutherford, 1995), motivation and expectations (Charlton et al., 2006), preparedness, choice compatibility and external circumstance (Ozga and Sukhnandan, 1998). Such work indicates that what a student experiences whilst studying and how they perceive university influences withdrawal decisions. This assertion is supported by Roberts et al (2003) who reported that a student's course, financial and personal perceptions were associated with intention to leave university during the first year of study rather than specific 'at risk' characteristics. Likewise, Mackie (2001) found that the problems that university drop outs experience were no worse than those encountered by persisters. Rather a key difference between leavers and doubters is their university commitment. Specifically, leavers' commitment was eroded through university experiences or was initially too low to sustain the student. Collectively, this signifies that students face a range of challenges during their 
time at university. It is therefore very important that academics and university support staff are familiar with the range of issues that students might encounter to ensure that their progression can be effectively supported.

However, one might question how well lecturers, pastoral support staff and learning developers actually appreciate the range of events students experience whilst studying. Storm (1973) outlined that behaviour is interpreted differently depending upon whether an individual is a situation actor (actively participating within a situation) or a situation observer (watching other people who are involved in a situation). An actor will 'watch their environment (which includes the behaviour of other people) more than they watch their own behaviour' (Storm, 1973: 166) whereas an observer will focus less upon a situation and more upon an actor. Based on this premise, individuals will perceive the student experience differently depending upon whether they are 'acting' or 'observing' the student role. This would suggest there could be misunderstandings between students and staff around aspects of the student experience. This is supported by Ozga and Sukhnandan (1998) who found evidence that some academic staff employed stereotypical views to explain typical reasons why students dropped out from university.

The likelihood of misperceptions is increased given that many university staff, be they academic or support, will not possess first-hand situational experience of what it is like to be a modern student because they graduated before HE reforms were introduced. To compensate for this, they are likely to base their understanding of student needs and behaviour on their own HE experiences, which are likely to be very different and possibly outdated. Likewise, they might consult with colleagues, who themselves might have dated HE perceptions and firmly grounded institutional perspectives of the student experience.

It is possible that university staff will consult published literature in order to conceptualise the student experience. However, when one reviews previous literature, it is apparent that there are limitations around research scope and content that could easily bias a reader's perception. One might suggest such perceptions could emerge because a disproportionate amount of research has focused extensively upon the experience of university dropouts (Yorke, 1999a, 1999b, 2000a, 2000b; Yorke and Longden, 2004) rather than those who persist. 
Furthermore, a significant proportion of the work that has addressed the experience of student 'persisters' has typically focused on predetermined events (Christie et al., 2002; Curtis and Shani, 2002) rather than addressing the events that shape the student persister experience in a grounded fashion. It is therefore suggested that potentially, individuals who have relied heavily upon secondary observations might not realise that they hold misperceptions around how students experience aspects of university.

Given this potential for discrepancy between staff and student perceptions of the student experience, it is surprising that little work has attempted to ascertain whether perceptions held by staff are in line with student accounts. Furthermore, the limited work that has been undertaken around this area has typically focused on very specific aspects of the university experience, such as employment (Metcalf, 2003; Curtis, 2005), rather than adopting a more generalist approach. Consequently, there was a need for research to be undertaken to establish how accurately university staff perceived aspects of the student experience without placing emphasis on predetermined areas of interest. This provided the rationale for this study.

\section{Method and results}

\section{Phase I - scope}

Work reported in this paper was a pilot study that formed part of a larger investigation into how students changed whilst studying at university. This pilot study raised a number of interesting findings associated with events students encountered during their academic career which are discussed within this article. Furthermore, through this work questions were also raised associated with group variations around, for example, what events are experienced during university, when events occur whilst a student is studying and whether there are variations in event perceptions between different student cohorts. Addressing each of these issues is beyond the scope of this article but has formed the basis for an ongoing PhD (currently being undertaken by the first author). Results that are presented should therefore not be seen as conclusive but rather as a basis from which some key questions associated with student support best practice have emerged. 


\section{Phase I - participants}

Data was collected from students and staff from a post-1992 UK university. The university student population was broadly representative of post-1992 institutions. Each participant participated in one semi-structured interview about the difficulties that students experience whilst studying at university. Both students and university staff were interviewed. Student participants were asked to discuss their own university experience whereas university staff were asked to draw upon their experience of working with students. Interviews took place between March and June 2007.

\section{Students}

Eighteen students participated in semi-structured interviews about the difficulties they had experienced during university. All of students were studying during the 2006-2007 academic year. The majority of participants were women $(n=12)$ and from the UK $(n=14)$. Participants represented a diverse range of ages $(\underline{M}=33.56 ; \underline{S D}=11.485)$ and ethnic backgrounds. Participants were recruited from first, second and third years of their degree programme (6 students from each) and represented a range of faculties.

\section{Staff}

Seven university staff participated in semi-structured interviews that addressed what difficulties they perceived students typically experienced. All staff worked at the same university within either a support $(n=5)$ or academic capacity $(n=2)$. The majority of staff were male $(n=4)$. Participants had a range of different experiences around working within HE. Support staff worked in a variety of pastoral roles (including learning development).

\section{Phase I - data collection and analysis}

Semi-structured interviews were used to collect data. Prior to analysis, interviews were transcribed and checked to ensure accuracy. A grounded theory approach (Glaser and Strauss, 1967) was applied, in that findings from previous research were not used as a basis for developing an interview-coding frame.

A coding frame emerged through the analysis of transcripts. In total, eleven types of difficulty (themes) were identified. Once a parsimonious coding frame was established 
theme definitions were written. This defined coding frame was then used to analyse interview content. To ensure that the coding frame was applied reliably, two of the authors independently coded an interview transcript using the coding frame. No pronounced differences in coding frame application were identified.

\section{Phase I - results}

Eleven main themes emerged that represented types of difficulty that students experienced. It should, however, be noted that many themes were reported by staff and students as being interrelated and participants seldom reported that difficulties occurred in isolation, as illustrated by the following metaphor used by a lecturer:

That ball I mentioned earlier where problems get tangled up with each other.

This quote highlights how students typically experience multiple problems (the ball) which are usually interrelated (get tangled up). For example, a student might experience financial issues whilst studying, so they get a part-time job. By undertaking employment they reduce their financial pressure but experience new problems related to time availability. Consequently, study time is reduced which leads to issues around academic performance. This assertion is supported by Roberts et al. (2003) who reported that students with higher doubt about remaining at university cited more reasons why they wanted to leave. Similarly, Christie et al. (2004) found that students typically cite on average 2.9 reasons why they withdraw from university.

Therefore, whilst it is acknowledged that difficulties seldom occur in isolation, themes are presented in a segmented fashion to aid interpretation of findings. Table 1 provides theme definitions and indicates the percentage of participants who discussed each theme: 
Table 1. Definition of difficulty themes and frequency of reporting.

\begin{tabular}{|c|c|c|c|}
\hline Theme & Definition & $\begin{array}{l}\text { Reported } \\
\text { by \% of } \\
\text { students }\end{array}$ & $\begin{array}{l}\text { Reported } \\
\text { by } \% \text { of } \\
\text { staff }\end{array}$ \\
\hline $\begin{array}{l}\text { Academic } \\
\text { skills/work }\end{array}$ & $\begin{array}{l}\text { Difficulties around academic work and/or } \\
\text { in relation to developing the skills } \\
\text { associated with undertaking academic } \\
\text { work. For example, difficulty in relation } \\
\text { to writing, maths or assessments. }\end{array}$ & $100 \%$ & $100 \%$ \\
\hline $\begin{array}{l}\text { Relationships } \\
\text { /interactions }\end{array}$ & $\begin{array}{l}\text { Difficulties linked to interactions with } \\
\text { other people. For example, difficulty } \\
\text { when interacting with academic staff, } \\
\text { students, non-academic staff or people } \\
\text { outside university. }\end{array}$ & $100 \%$ & $100 \%$ \\
\hline $\begin{array}{l}\text { Time } \\
\text { conflicts }\end{array}$ & $\begin{array}{l}\text { Difficulties related to competing } \\
\text { demands on student time. For example, } \\
\text { time pressure associated with studying } \\
\text { or activities external to university. }\end{array}$ & $89 \%$ & $100 \%$ \\
\hline $\begin{array}{l}\text { Course } \\
\text { related }\end{array}$ & $\begin{array}{l}\text { Difficulties experienced because of } \\
\text { issues specific to a programme of study. } \\
\text { For example, receiving limited } \\
\text { information, teaching content/style or } \\
\text { issues around attending a placement. }\end{array}$ & $67 \%$ & $28 \%$ \\
\hline Finances & $\begin{array}{l}\text { Difficulties linked to financial } \\
\text { discrepancies that students incur. For } \\
\text { example, financial outgoings, level of } \\
\text { income or budgeting. }\end{array}$ & $61 \%$ & $71 \%$ \\
\hline Transitions & $\begin{array}{l}\text { Difficulties around university transitions. } \\
\text { For example, starting university, moving } \\
\text { between levels of study or the prospect } \\
\text { of leaving university. }\end{array}$ & $56 \%$ & $86 \%$ \\
\hline
\end{tabular}




\begin{tabular}{|c|c|c|c|}
\hline Theme & Definition & $\begin{array}{l}\text { Reported } \\
\text { by } \% \text { of } \\
\text { students }\end{array}$ & $\begin{array}{l}\text { Reported } \\
\text { by } \% \text { of } \\
\text { staff }\end{array}$ \\
\hline $\begin{array}{l}\text { Student's } \\
\text { state of } \\
\text { mind }\end{array}$ & $\begin{array}{l}\text { Difficulties experienced due to how a } \\
\text { student perceives himself/herself and/or } \\
\text { how they feel. For example, anxiety, low } \\
\text { confidence or negative self-belief. }\end{array}$ & $56 \%$ & $71 \%$ \\
\hline $\begin{array}{l}\text { Mental/ } \\
\text { physical } \\
\text { state }\end{array}$ & $\begin{array}{l}\text { Difficulties around mental or physical } \\
\text { condition that impact on a student. For } \\
\text { example, difficulty because of personal } \\
\text { health or the health of a significant other. }\end{array}$ & $50 \%$ & $100 \%$ \\
\hline $\begin{array}{l}\text { Access } \\
\text { university } \\
\text { services/ } \\
\text { facilities }\end{array}$ & $\begin{array}{l}\text { Difficulties experienced in relation to } \\
\text { utilising facilities/services that should be } \\
\text { available to all students. For example, } \\
\text { online learning materials, study support, } \\
\text { career advice, workshops, learning } \\
\text { resources. }\end{array}$ & $50 \%$ & $14 \%$ \\
\hline $\begin{array}{l}\text { Place of } \\
\text { residence }\end{array}$ & $\begin{array}{l}\text { Difficulty associated with where students } \\
\text { are living. }\end{array}$ & $28 \%$ & $57 \%$ \\
\hline $\begin{array}{l}\text { Culture/ } \\
\text { religion }\end{array}$ & $\begin{array}{l}\text { Difficulties because of religious belief } \\
\text { and/or linked to their cultural background. } \\
\text { For example, religious belief conflict or } \\
\text { integrating into a new culture. }\end{array}$ & $22 \%$ & $57 \%$ \\
\hline
\end{tabular}

In addition to establishing that difficulties seldom occur in isolation, it was found that generally, university staff have a sound awareness of most issues associated with the student experience. As shown, variations were, however, found in the level of agreement around the salience of certain themes. Specifically, three distinct levels regarding the alignment of staff and student perceptions were identified (presented in Table 2). 
Table 2. Levels of agreement between students and staff.

\begin{tabular}{|c|c|c|}
\hline $\begin{array}{l}\text { Type of } \\
\text { agreement }\end{array}$ & Themes & Description \\
\hline $\begin{array}{l}\text { Close } \\
\text { agreement }\end{array}$ & $\begin{array}{l}\text { Academic skills/ } \\
\text { work } \\
\text { Relationships/ } \\
\text { interactions } \\
\text { Finances } \\
\text { Time conflicts }\end{array}$ & $\begin{array}{l}\text { Close consensus between staff and } \\
\text { student reporting. }\end{array}$ \\
\hline $\begin{array}{l}\text { Proportionally } \\
\text { over-reported } \\
\text { by staff }\end{array}$ & $\begin{array}{l}\text { Transitions } \\
\text { Mental physical } \\
\text { condition } \\
\text { Student's state of } \\
\text { mind } \\
\text { Place of } \\
\text { residence } \\
\text { Culture/religion }\end{array}$ & $\begin{array}{l}\text { Themes were proportionally perceived by } \\
\text { university staff to be more typical than } \\
\text { students' accounts suggested. } \\
\text { A number of staff referred to examples of } \\
\text { specific students or small cohorts when } \\
\text { discussing these themes (however, } \\
\text { reference to specific students was not } \\
\text { restricted solely to areas that were over } \\
\text { reported). Possible explanations for staff } \\
\text { over reporting are considered in the } \\
\text { discussion. }\end{array}$ \\
\hline $\begin{array}{l}\text { Proportionally } \\
\text { under-reported } \\
\text { by staff }\end{array}$ & $\begin{array}{l}\text { Course related } \\
\text { Accessing } \\
\text { university } \\
\text { services and } \\
\text { facilities }\end{array}$ & $\begin{array}{l}\text { Themes associated with areas where } \\
\text { staff appeared to under appreciate the } \\
\text { difficulties that students experienced. }\end{array}$ \\
\hline
\end{tabular}

Further analysis was undertaken around the proportionally under-reported themes to establish if limited staff awareness was specific to certain aspects of themes. Findings indicated the main reasons why students reported course-related difficulties was linked to 
quality of information, organisation of teaching and issues linked to placement attendance. In terms of accessing university services/facilities, it was found that the main types of issue stemmed from service availability and accessibility. Collectively, findings suggested university staff generally had a limited knowledge of these areas. Further, those staff who did report student difficulties around these areas had typically discussed recent experiences.

\section{Phase II - overview}

As noted, phase 1 comprised an early stage of ongoing student experience research. Interview data was used (in conjunction with other project data that is not reported) as the basis for developing an online questionnaire that incorporated 81 'typical' life events related to university study (this included positive events as well as difficulties). This questionnaire was emailed to university staff to ascertain what events they perceived to be most typically experienced by students at some point during their time at university (based on their own experiences of working with students). Participants were asked to indicate on a five point scale the extent to which they thought each event was typical of the student experience. If respondents were unsure about event occurrence they were asked to select an 'unsure' option.

Using online life event questionnaire results, the researchers attempted to establish whether the proportional underreporting of difficulties linked to course and accessing university services and facilities was evident amongst staff per se. Consequently, the authors considered the types of events to which university staff responded 'unsure' and so indicating with which they were less familiar.

\section{Phase II - participants}

An invitation to complete the online questionnaire was sent to 281 university staff at a post 1992-university (between October and November 2008). In total, 94 staff (34\%) completed the questionnaire. Participants represented a range of support areas $(n=27)$ such as learning development, finance advice, librarians and disability support, and lecturers ( $\mathrm{n}=$ 67) across academic faculties. 


\section{Phase II - data collection and analysis}

Data presented in this section indicates which aspects of the university experience staff appeared least and most familiar. These areas were identified based on the proportion of participants who selected the 'unsure' option when completing the online questionnaire.

\section{Phase II - results}

The average 'unsure' rating was $17.9 \%$ which indicated that generally the majority of the sample was able to indicate how typical each event was in terms of the student experience. Broadly online questionnaire results supported interview findings. These results are highlighted in table 3 and table 4

Table 3. Online questionnaire items that received the highest number of participant unsure responses.

\begin{tabular}{|l|c|}
\hline University Events & $\begin{array}{l}\% \text { of unsure } \\
\text { responses (all } \\
\text { respondents) }\end{array}$ \\
\hline $\begin{array}{l}\text { Accessed university language centre services } \\
\text { (Provides support to international students around the } \\
\text { development of linguistic skills) }\end{array}$ & $46 \%$ \\
\hline Accessed university chaplaincy services & $45 \%$ \\
\hline Change in where they study & $40 \%$ \\
\hline Change in who a student studies with & $36 \%$ \\
\hline Change in when they study & $33 \%$ \\
\hline Participated in university sports team & $32 \%$ \\
\hline Accessed Centre for Personal and Career Development & $31 \%$ \\
\hline $\begin{array}{l}\text { Accessed university counselling service } \\
\text { Accessed university financial support services }\end{array}$ & $30 \%$ \\
\hline Accessed student union services & $29 \%$ \\
\hline
\end{tabular}


Table 4. Online questionnaire items that received the lowest number of participant unsure responses.

\begin{tabular}{|l|c|}
\hline University Events & $\begin{array}{l}\% \text { of unsure } \\
\text { responses } \\
\text { (all } \\
\text { respondents) }\end{array}$ \\
\hline $\begin{array}{l}\text { Attended seminar/tutorial } \\
\text { Received academic advice from lecturers }\end{array}$ & $4 \%$ \\
\hline $\begin{array}{l}\text { Gave a presentation } \\
\text { Communicated with lecturers }\end{array}$ & $2 \%$ \\
\hline $\begin{array}{l}\text { Sat an exam } \\
\text { Received grades }\end{array}$ & $1 \%$ \\
\hline $\begin{array}{l}\text { Attended lecture(s) } \\
\text { Assignment writing } \\
\text { Group work } \\
\text { Dissertation writing }\end{array}$ & $0 \%$ \\
\hline
\end{tabular}

As can be seen, university staff appeared to have limited awareness of events that occurred beyond their own direct experience of working with students. This is evident in the fact that staff were least aware of student usage of particular university services and facilities and the nature of typical student study behaviours. In contrast, staff appeared most familiar about events associated with their own direct student contact (such as the occurrence of academic and relationship based events) in line with interview findings.

\section{Summary}

When considered collectively, results suggested that university staff broadly had a good awareness of most events related to university study and were familiar with many of the issues that students faced. However, certain staff appeared less familiar about the typicality of particular types of events linked to academic study (associated with facility and service usage). This conclusion is supported by both interview and online questionnaire data. Explanations for these findings are presented in the discussion. 


\section{Discussion}

Unsurprisingly the range of events that students and staff reported were generally found to be broadly in line with those that have been previously documented (Yorke, 1999a, 1999b, 2000a, 2000b; Haggis and Pouget, 2002; Curtis and Shani, 2002; Hutchings, 2003; Cooke et al, 2004; Carney et al., 2005). However, unlike previous research, this study begins to provide a valuable insight into the salience and frequency of event occurrence that is reported by students and how this is perceived by university staff. This in turn has generated some interesting findings and raised some important questions. Nonetheless, as stated, this article is based on a limited sample of participants, therefore these early conclusions must be treated with some caution. It is intended that this work will be expanded through an ongoing body of research which will permit more robust conclusions to be drawn.

Generally, results indicated that university staff have a good awareness of the range of issues that affect students (broadly in line with Metcalf, 2003). There do, however, appear to be certain areas where staff awareness of the student experience is not in line with student accounts (offering partial support for Curtis, 2005). Overall, results highlighted areas of under-reporting which suggested that within a university, certain staff (both academic and learning support) may suffer from a 'knowledge gap' associated with aspects of the student experience that fall outside of their own job remit. In this instance, knowledge gaps were primarily found to be associated with how students utilised university facilities and services. However, it is possible that had other staff been interviewed other knowledge gaps might have been identified, peculiar to other aspects of the university.

Within a university, this type of awareness deficit could affect staff promotion of service availability, which could easily undermine aspects of the student experience. Support for this conclusion can be found in the National Student Satisfaction Survey (NSSS) results (HEFCE, 2007). NSSS results appeared to confirm a large number of students experience problems around university-based services and facilities in that, nationally, $20 \%$ of students were not satisfied with university learning resources and $29 \%$ were unsatisfied with the provision of academic support from their university. 
It might be that discrepancies in reporting relate to differences in how staff and students perceive the university. Specifically, experienced university staff will have become acquainted with the university systems and staff that they need to know about in order to do their job. It is therefore suggested that most staff form a segmented perception of university which means departments with which they have little or no contact do not form part of their general university related thinking. This is in stark contrast to how students will experience university, in that students need to perceive university in a holistic fashion, knowing about a range of services that cross over university departments, in order to get the most from their studies. This assertion would appear to be in line with online questionnaire results which highlighted that areas synonymous with under-reporting were also those that staff knew less about in terms of student usage.

As noted, there were certain areas (such as, religion or accommodation) that university staff over reported. Potentially, this finding could also be a cause for concern for those who work with university students. An individual with inaccurate perceptions about event frequency could reach incorrect conclusions about how best to support their students. As identified, the issues that students reported seldom occurred in isolation. It could therefore be argued that when issues associated with university facilities occur in conjunction with more common or 'well-defined' issues (such as, finances or academic work) staff who are trying to support the student automatically focus on the well-defined difficulty and fail to fully appreciate the influence of other factors. They may well adopt a hierarchical framework of conceptual/perceptual categories which differs both from those of students and colleagues in other parts of the university. However, given the limited sample size, further work would be necessary to confirm this assertion.

There are a number of explanations as to why certain events were viewed to be most salient. When discussing the student experience, staff might have focused on students who stood out during their career but were not typical of the student population. One might propose that such students represented complex cases, which consumed large amounts of time and effort and had a disproportionate influence upon perceptions of 'typical' students. During interviews a number of staff referred to a specific student or cohort when discussing over reported areas, which would appear to offer tentative support for this assertion. Likewise, during interviews it was found that staff who worked within a specific area disproportionately focused on factors related to their own department. For example, unsurprisingly the university chaplain focused on religious difficulties. It might therefore be 
proposed that staff knowledge of the 'typical' student experience will be biased by where they work within a university and their own background. Equally, it is possible that staff will attempt to provide excessive support in certain areas so as to meet institutional priorities or reduce the possibility of receiving criticism.

It is also possible that students might only be more willing to discuss specific types of difficulties with university staff. Should this be the case, edited accounts of the university experience reported by students could easily distort an individual's perspective of modern day academic study. This notion was not explicitly addressed during interviews but could form the basis for insightful future research.

However, some more specific issues should be borne in mind in interpreting findings. Firstly, the study design can only provide a snapshot of students' experience taken from one point in time. This design relies upon students accurately remembering previous experiences. It is recognised that students will change during university, which in turn could have influenced how they report previous events. Currently, further work is being undertaken that aims to track events that students experience whilst studying over an extended period using a longitudinal methodology. This methodological approach will enable a very accurate identification of specific periods of the student career that are associated with certain types of experience and whether specific university events are ongoing. Furthermore, this work will establish how students perceive different types of events that they encounter. It is hoped that this approach will be of significant use in terms of informing university policy around student development and retention.

As noted, results from this study will have limited generalisability and cannot be easily generalised due to sample size. Likewise, the sample was recruited from one UK post1992 university and is not therefore representative of HE institutions per se. To help learn general lessons, improved generalisability work might establish if findings are applicable to a larger sample of students. Similarly, a larger sample would make it possible to establish if there are between group differences amongst student perceptions of the student experience. Again, research is currently being undertaken around these areas. 
Therefore, to the extent that the findings reported above are representative, the following recommendations might be tentatively adduced:

Learning developers should actively consider what factors could bias their understanding of university students' experience and look for ways in which a better appreciation of what students encounter and experience can be developed. This might involve making use of existing resources such as, the Student Transition And Retention (STAR) project (Cook, 2006). Staff might consider setting up working groups that allow colleagues from different university departments to share experiences of working with students. Similarly, student focus groups could be used to identify what issues affect students as they move through their studies; results could then be disseminated to university staff.

Periodic updating of staff knowledge of student difficulties through staff development activities might be employed. Such activities could involve representatives from less wellknown areas of the university (in some cases this could include a learning development unit) formally meeting with colleagues to discuss what service they provide. The focus of such training could be based on results from 'in-house' student satisfaction questionnaires or findings from national student surveys. Undertaking this type of staff development activity will help to eliminate out-of-date stereotypes associated with the university experience that might influence how student learning is promoted and supported.

\section{Conclusion}

Although only a pilot study, this research has raised a number of important issues associated with what students experience during university and how this is perceived by university staff. Findings clearly indicate that students experience a wide range of difficulties during their time at university. Reassuringly, university staff generally have an accurate and broad understanding of many events that comprise the student experience. However, there would appear to be areas where staff do not accurately perceive students' university experience. It is argued that knowledge gaps of this nature could potentially affect how effectively students are supported in certain aspects of their studies. It is planned that through subsequent work a greater and more detailed understanding of many of the issues raised by this article will emerge. 


\section{References}

Andrews, B. and Wilding, J.M. (2004) 'The relation of depression and anxiety to life-stress and achievement in students', British Journal of Psychology 95 pp 509-521.

Anonymous. (2006) 'Long hours and soaring debts are 'lethal cocktail' for students', Nursing Standard 21(14-16) pp 6.

Carney, C., McNeish, S. and McColl, J. (2005) 'The impact of part time employment on students' health and academic performance: a Scottish perspective', Journal of Further and Higher Education 29(4) pp 307-319.

Charlton, J.P., Barrow, C. and Hornby-Atkinson, P. (2006) 'Attempting to predict withdrawal from higher education using demographic, psychological and educational measures', Research in Post-Compulsory Education 11(1) pp 31-47.

Christie, H., Cree, V.E., Hounsell, J., McCune, V. and Tett, L. (2006) 'From college to university: looking backwards, looking forwards', Research in Post-Compulsory Education 11(3) pp 351-365.

Christie, H., Munro, M. and Fisher, T. (2004) 'Leaving university early: exploring the differences between continuing and non-continuing students', Studies in Higher Education 29(5) pp 617-636.

Christie, H., Munro, M. and Rettig, H. (2002) 'Accommodating students', Journal of Youth Studies 5(2) pp 209-235.

Christie, H., Munro, M. and Wager, F. (2005) "Day students' in higher education: widening access students and successful transitions to university life', International Studies in Sociology of Education 15(1) pp 3-29.

Cook, T. (2006) Student Transition And Retention (The STAR Project). ONLINE: http://www.ulster.ac.uk/star/index.htm (Accessed: 13 December 2009). 
Cooke, R., Barkham, M., Audin, K., Bradley, M. and Davy, J. (2004) 'How social class differences affect students' experiences of university', Journal of Further and Higher Education 28(4) pp 407-421.

Curtis, S. (2005) 'Support for working undergraduates: the view of academic staff', Education and Training 47(7) pp 496-505.

Curtis, S. and Shani, N. (2002) 'The effect of taking paid employment during term-time on students' academic studies', Journal of Further and Higher Education 26(2) pp 130138.

Department for Education and Skills (2003) Widening participation in higher education. ONLINE: http://www.dfes.gov.uk/hegateway/uploads/EWParticipation.pdf (Accessed: 20 January 2009).

Gibbs, G. (2006) 'Why assessment is changing', pp.11-22, in Bryan, C. and Clegg, K. (eds.) Innovative assessment in higher education. London: Routledge.

Glaser, B.G. and Strauss, A.L. (1967) The discovery of grounded theory: strategies for qualitative research. USA: Aldine Publishing Company.

Haggis, T. and Pouget, M. (2002) 'Trying to be motivated: perspectives on learning from younger students accessing higher education', Teaching in Higher Education 7(3) pp 323 - 336.

Higher Education Funding Council for England (1997) Research series M8/97: the participation of non-traditional students in higher education. ONLINE: http://www.hefce.ac.uk/Pubs/hefce/1997/m8 97.htm (Accessed: 20 January 2009).

Higher Education Funding Council for England (2006) Widening participation: a review: report to the minister of state for higher education and lifelong learning by the Higher Education Council for England. ONLINE: http://www.hefce.ac.uk/widen/aimhigh/WPfinalreview.pdf (Accessed: 20 January 2009). 
Higher Education Funding Council for England (2007) Higher education survey reveals continued student satisfaction. ONLINE:

http://www.hefce.ac.uk/news/hefce/2007/nss.htm (Accessed: 20 January 2009).

Hughes, S.J. (2005) 'Student attendance during college-based lectures: a pilot study', Nursing Standard 19(47) pp 41 - 49.

Hunt, A., Lincoln, I. and Walker, A. (2004) 'Term-time employment and academic attainment: evidence from a large-scale survey of undergraduates at Northumbria University“, Journal of Further and Higher Education 28(1) pp 3-18.

Hutchings, M. (2003) 'Financial barriers to participation', pp. 155-173, in Archer, L., Hutchings, M. and Ross, A. (eds.) Higher education and social class: issues of exclusion and inclusion. Trowbridge: Routledge Farmer.

Mackie, S.E. (2001) 'Jumping the hurdles - undergraduate student withdrawal behaviour', Innovations in Education and Teaching International 38(3) pp 265-276.

Metcalf, H. (2003) 'Increasing inequality in higher education: the role of term-time working', Oxford Review of Education 29(3) pp 315-329.

Ozga, J. and Sukhnandan, L. (1998) 'Undergraduate non-completion: developing an explanatory model', Higher Education Quarterly 52(3) pp 316-333.

Pollock, I. (2006) New students face future of debts. ONLINE: http://news.bbc.co.uk/1/hi/business/5274342.stm (Accessed: 20 January 2009).

Rickinson, B. and Rutherford, D. (1995) 'Increasing undergraduate student retention rates', British Journal of Guidance and Counselling 23(2) pp 161-172.

Roberts, C., Watkin, M., Oakey, D. and Fox, R. (2003) Supporting students' 'success': What can we learn from persisters? ONLINE: http://usir.salford.ac.uk/1208/1/ECE paper 2003.pdf (Accessed: 13 December 2009). 
Sayer, M., Chaput De Saintonge, M., Evans, D. and Wood, D. (2002) 'Support for students with academic difficulties', Medical Education 36 pp 643-650.

Storm, M.D. (1973) 'Videotape and the attribution process: reversing actors' and observers' points of view“, Journal of Personality and Social Psychology 27(2) pp 165-175.

Tinto, V. (1975) 'Dropout from higher education: a theoretical synthesis of recent research', Review of Educational Research 45(1) pp 89-125.

Wilcox, P., Winn, S. and Fyvie-Gauld, M. (2005) 'It was nothing to do with the university, it was the people: the role of social support in the first-year experience of higher education', Studies in Higher Education 30(6) pp 707-722.

Yorke, M. (1999a) 'Student withdrawal during the first year of higher education in England', Journal of Institutional Research in Australia, [online], http://www.aair.org.au/jir/May99/Yorke.pdf [Accessed: 21 March 2007].

Yorke, M. (1999b) Leaving early: undergraduate non-completion in higher education. Great Britain: Falmer Press.

Yorke, M. (2000a) 'The quality of the student experience: what can institutions learn from data relating to non-completion?', Quality in Higher Education 6(1) pp 61-75.

Yorke, M. (2000b) 'Smoothing the transition into higher education: what can be learned from student non-completion?', Journal of Institutional Research 9(1).

Yorke, M. and Longden, B. (2004) 'Why students leave their programmes', pp. $103-119$, in Yorke, M. and Longden, B. (eds.) Retention and student success in higher education. Cornwall: Society for Research into Higher Education and Open University Press. 


\section{Author details}

Steve Briggs currently works as a Learning Development Tutor in PAD (The Professional and Academic Development Team) based at the University of Bedfordshire. He is currently undertaking a part time $\mathrm{PhD}$ investigating the nature and timing of events associated with studying at university and how these shape student development.

Norma Pritchett is Dean of Students at the University of Bedfordshire. She is a chartered psychologist with interests in the psychology of teaching and learning in Higher Education. 